$1-1-1964$

\title{
Composition and production of poultry manure
}

B. W. Moore

Follow this and additional works at: https://researchrepository.wvu.edu/ wv_agricultural_and_forestry_experiment_station_bulletins

\section{Digital Commons Citation}

Moore, B. W., "Composition and production of poultry manure" (1964). West Virginia Agricultural and Forestry Experiment Station Bulletins. 496T.

https://researchrepository.wvu.edu/wv_agricultural_and_forestry_experiment_station_bulletins/655 @ WVU. It has been accepted for inclusion in West Virginia Agricultural and Forestry Experiment Station Bulletins by an authorized administrator of The Research Repository @ WVU. For more information, please contact ian.harmon@mail.wvu.edu. 

Digitized by the Internet Archive in 2010 with funding from Lyrasis Members and Sloan Foundation 


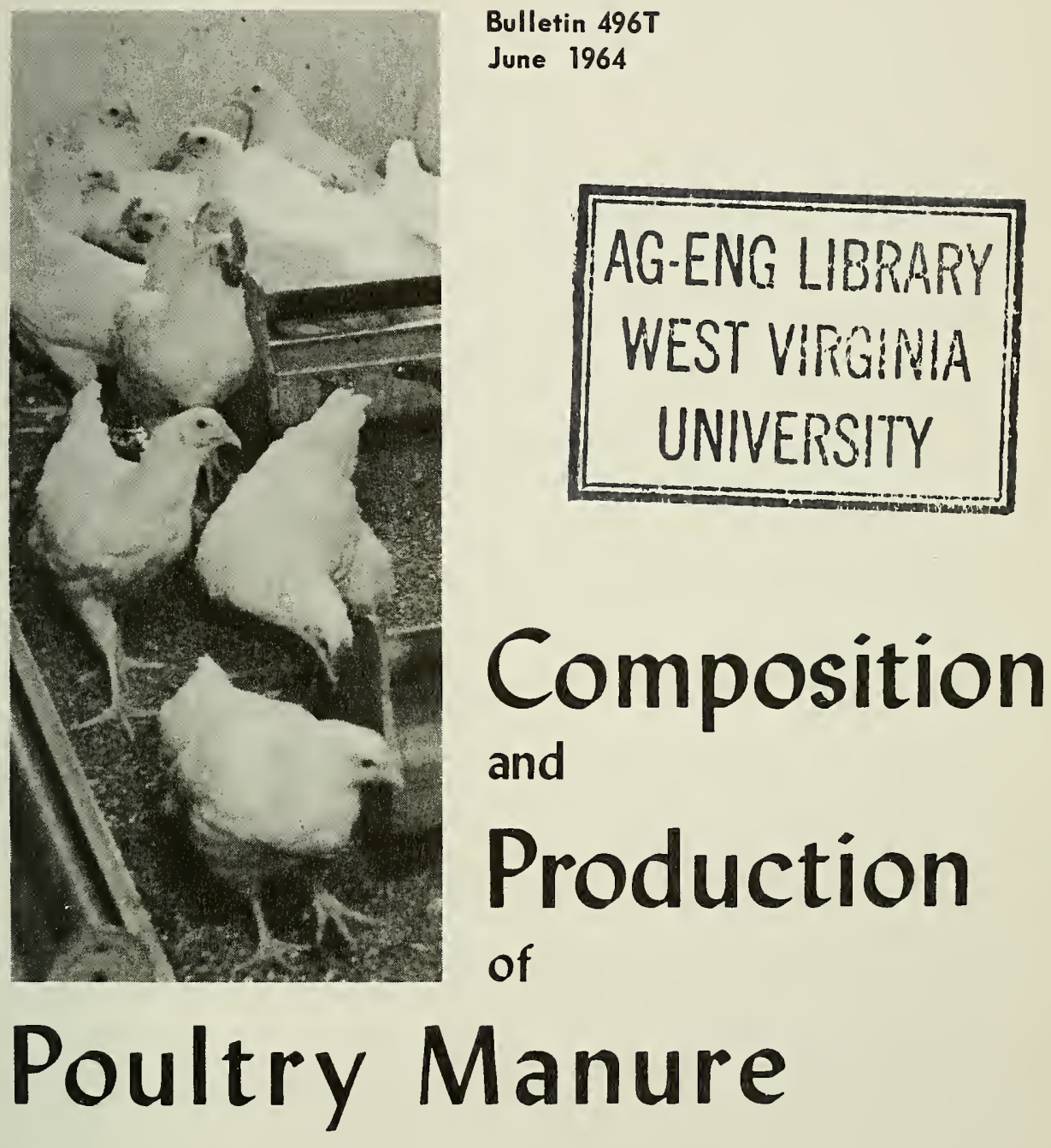

West Virginia University Agricultural Experiment Station 


\section{THE AUTHORS}

B. W. Moore is State Extension Poultry Specialist, Cooperative Extension Service; Homer Patrick is Professor and Chairman of Agricultural Biochemistry and Agricultural Biochemist in the Agricultural Experiment Station; J. R. Johnson is Research Assistant, Department of Animal Industry and Veterinary Science; and H. M. Hyre is Associate Professor of Poultry Science and Associate Poultry Scientist in the Agricultural Experiment Station.

Acknowledgment

The authors wish to acknowledge the assistance of Marvin H. Snyder, Chief Chemist, State Department of Agriculture, Charleston, for the analytical determinations made in this study.

WEST VIRGINIA UNIVERSITY

AGRICULTURAL EXPERIMENT STATION

College of Agriculture, Forestry, AND Home Economics

A. H. Vanlandingham, DiRector

MORGANTOWN 


\section{Composition and Production Of Poultry Manure}

B. W. Moore, H. Patrick, J. R. Johnson, and H. M. Hyre

Poultry manure is not utilized to the fullest extent by poultrymen, perhaps because they do not realize its value.

The nitrogen in this manure is primarily in the form of uric acid, and microorganisms readily decompose the uric acid, forming ammonia which escapes into the air.

The amount of manure voided by hens and broilers is influenced by composition of the ration, environmental temperature, age, and physiological status. Some feed combinations consisting of meat and soybean meal increase the quantity of manure. The moisture content of poultry manure remains rather constant, $72-74$ per cent; however, salt $(\mathrm{NaC} 1)$, accessibility to water such as in cage operations, calcium sulfate, and some proteins can influence moisture content. Visual appearance of the manure is not an accurate index to its moisture content. The moisture in manure is in a colloidal state and a change in colloidal state can produce visual changes, with little variation in actual moisture content. When the colloidal structure of poultry manure is molested, a congealing mass is produced-as results with daily use of a pit cleaner-and drying-out does not readily occur.

\section{PURPOSE OF STUDY}

The purpose of this study was to (1) determine the ratio of feed consumption to manure production in laying hens and determine the relative water content of fresh manure in a cage-managed operation and in a loose house operation with pit roosting, feeding and watering; (2) compute and show the comparative analysis of manure produced under the two systems of management; (3) determine the dry weight increase and comparative analysis of litter during the replacement brooding period using sawdust and Zorbit litter material. 


\section{CAGE AND MANAGEMENT OPERATION}

During the week of July 9-14, 1962, daily manure production from 360 hens in cages was collected and weighed. A record of feed consumption and egg production was maintained. Outside temperature and precipitation readings were obtained from the local airport. Moisture content was calculated from fresh manure samples collected and dried in an electrically heated forced air oven for a 48 -hour period at a temperature of approximately $120^{\circ} \mathrm{F}$.

The cage area consisted of eight rows of 8-inch cages, with four rows over each of two pits. Each pit was equipped with a manure scraper. The hens, inbred cross Leghorns, were placed individually in $8 \times 16$-inch cages.

The room was ventilated with "pressure-type" intake wall fans.

\section{LOOSE HOUSING, FLOOR OPERATED WITH PITS}

During the week of July 16-21, 1962, droppings from the roosting, feeding and watering pits were collected and weighed daily from the loose housing pen. The feeders, waterers and roosts were located above the pits. Approximately 1,000 inbred Leghorn hens were used during this study. About two square feet of floor space was provided for each laying hen. Ventilation and insulation in this house were identical to that in the cage house.

\section{LITTER MANAGEMENT DURING THE BROODING PERIOD}

Twelve pens $10 \times 14$ feet were utilized to study manure accumulation over a period ranging from 80 to 90 days from July 8 through October 6, 1962. Approximately 165 chicks were started in each pen. Gas space heaters maintained a uniform temperature throughout the building and the brooding heat was provided by four heat lamps per pen.

Seven pens each received an average of 277 pounds of wet sawdust as it came from the mill; one pen received 308 pounds of sawdust from a second source; and four pens received an average of 89 pounds each of commercial litter (Zorbit), a crushed cane stalk material. Moisture content of the three litter materials was determined on July 2 when the litter was placed in the pens. On July 7 , five days later, a second moisture check was made on all sawdust pens. A dry litter weight was computed for all pens. Records of feed consumption and mortality were maintained throughout the experimental period. When the birds were ready to be removed from the building, the accumulated litter from each pen was weighed, mixed, and samples were collected for determination of moisture content. 
Dry litter weight increases were computed per pen, per chick, per day and for each pound of feed consumed, and samples were analyzed to determine nitrogen, $\mathrm{P}_{2} \mathrm{O}_{5}$ and $\mathrm{K}_{2} \mathrm{O}$ content.

The results of these studies are presented in the following tables.

Table 1 is a summary of the poultry manure and litter, according to the literature. White et al. (1944) reported that floor litter manure lost 29.5 per cent of its original nitrogen when removed and stored elsewhere. It was also reported that 70.2 per cent of the total nitrogen in fresh hen manure was derived from urinary nitrogen and 29.8 per cent from fecal nitrogen (undigested protein residues). Yushok and Bear (1943) reported that 81 per cent of the nitrogen, 88 per cent of the $\mathrm{P}_{2} \mathrm{O}_{5}$ and 95 per cent of the $\mathrm{K}_{2} \mathrm{O}$ contained in the feed are voided in the manure.

Table 2 is a comparison of cage management with loose housing. The results obtained during this study, as summarized in this table, show that cage hens produced approximately 1.2 pounds of manure per pound of feed consumed and the hens in loose housing cast approximately .97 pounds of manure per pound of feed consumed in the pits.

According to these results, the moisture content of manure produced by cage hens is approximately 4 per cent above that produced by loose managed hens. During this study the temperature remained approximately the same in the loose and the cage-operated house $\left(81^{\circ}\right.$ to $\left.63^{\circ} \mathrm{F}\right)$. This indicates that moisture was not affected by temperature.

TABLE 1

REPORTED COMPOSITION OF POULTRY MANURE AND LITTER*

\begin{tabular}{|c|c|c|c|c|c|}
\hline Investigator & Description & $\begin{array}{l}\text { Mois ture } \\
\text { (per cent) }\end{array}$ & $\begin{array}{c}\mathrm{N} \\
\text { (per cen } t)\end{array}$ & $\begin{array}{c}\mathrm{P}_{2} \mathrm{O}_{5} \\
\text { (per cent) }\end{array}$ & $\begin{array}{c}\mathrm{K}_{2} \mathrm{O} \\
(\text { per cent) }\end{array}$ \\
\hline $\begin{array}{l}\text { Yushok and Bear, } \\
1954\end{array}$ & Old hen litter & 47.2 & 1.83 & 1.43 & 0.76 \\
\hline White et al., 1944 & Hen litter & 15.8 & 2.79 & 2.85 & 1.48 \\
\hline $\begin{array}{l}\text { Papanos and } \\
\text { Brown, } 1950\end{array}$ & $\begin{array}{l}\text { Droppings and } \\
\text { litter }\end{array}$ & 40. & 2. & 2. & 1. \\
\hline $\begin{array}{l}\text { Papanos and } \\
\text { Brown, } 1950\end{array}$ & $\begin{array}{l}\text { Fresh hen } \\
\text { manure (avg.) }\end{array}$ & & 1.4 & 1.2 & .57 \\
\hline Van Slyke, 1943 & $\begin{array}{l}\text { Fresh hen } \\
\text { manure (avg.) }\end{array}$ & 55. & 1. & .67 & .38 \\
\hline $\begin{array}{l}\text { Parker, Perkins, } \\
\text { and Fuller, } 1959\end{array}$ & Mixed litter & 36.9 & 2. & 1.9 & 1.88 \\
\hline Hileman, 1959 & $\begin{array}{c}\text { Broiler house } \\
\text { litter (avg.) }\end{array}$ & 28.86 & 4.1 & 3.36 & 2.41 \\
\hline $\begin{array}{c}\text { University of } \\
\text { Arkansas }\end{array}$ & $\begin{array}{l}\text { Manure with } \\
\text { litter }\end{array}$ & 30. & 2.8 & 2.3 & 1.8 \\
\hline
\end{tabular}

* Resu1ts expressed as per cent of dry matter. 
TABLE 2

FRESH MANURE PRODUCTION AND MOISTURE CONTENT USING TWO SYSTEMS OF HEN MANAGEMENT *

\begin{tabular}{lcccccc}
\hline $\begin{array}{c}\text { Management } \\
\text { system }\end{array}$ & $\begin{array}{c}\text { Number } \\
\text { birds }\end{array}$ & $\begin{array}{c}\text { Total wet } \\
\text { weight } \\
\text { (pounds) }\end{array}$ & $\begin{array}{c}\text { Wet manure } \\
\text { per hen } \\
\text { (pounds) }\end{array}$ & $\begin{array}{c}\text { Per hen } \\
\text { per day } \\
\text { (pounds) }\end{array}$ & $\begin{array}{c}\text { Dry } \\
\text { matter } \\
\text { (per cent) }\end{array}$ & $\begin{array}{c}\text { Average } \\
\text { moisture } \\
\text { (per cent) }\end{array}$ \\
\hline Cage & 630 & 762.73 & 1.21 & 0.242 & 25.65 & 74.35 \\
Loose housing & 1,013 & $978.80^{* *}$ & $0.966^{* *}$ & 0.193 & 29.84 & 70.16 \\
\hline
\end{tabular}

*Five-days production. **Represents manure from pits only.

TABLE 3

RELATION OF FEED CONSUMPTION AND EGG PRODUCTION TO FRESH MANURE PRODUCTION (FIVE.DAY CHECK) USING TWO SYSTEMS OF MANAGEMENT

\begin{tabular}{lcccccc}
\hline $\begin{array}{l}\text { Management } \\
\text { system }\end{array}$ & $\begin{array}{c}\text { Number } \\
\text { birds }\end{array}$ & $\begin{array}{c}\text { Egg } \\
\text { production } \\
\text { (per cent) }\end{array}$ & $\begin{array}{c}\text { Feed per } \\
\text { dozen eggs } \\
\text { (pounds) }\end{array}$ & $\begin{array}{c}\text { Feed per } \\
\text { bird per } \\
\text { day } \\
\text { (pounds) }\end{array}$ & $\begin{array}{c}\text { Manure } \\
\text { per bird } \\
\text { per day } \\
\text { (pounds) }\end{array}$ & $\begin{array}{c}\text { Average } \\
\text { moisture } \\
\text { (per cent) }\end{array}$ \\
\hline $\begin{array}{lcccccc}\text { Cage } \\
\text { Loose housing }\end{array}$ & 630 & 75.01 & 3.73 & 0.233 & 0.242 & 74.35 \\
\hline
\end{tabular}

*Represents manure from pits only.

TABLE 4

ANAYLSIS OF FRESH MANURE FROM HENS UNDER TWO SYSTEMS OF MANAGEMENT *

\begin{tabular}{lccccc}
\hline $\begin{array}{l}\text { Management } \\
\text { system }\end{array}$ & $\begin{array}{c}\text { Number } \\
\text { birds }\end{array}$ & $\begin{array}{c}\mathrm{N} \\
\text { (per cent) }\end{array}$ & $\begin{array}{c}\mathrm{P}_{2} \mathrm{O}_{5} \\
\text { (per cent) }\end{array}$ & $\begin{array}{c}\mathrm{K}_{2} \mathrm{O} \\
\text { (per cent) }\end{array}$ & $\begin{array}{c}\text { Average } \\
\text { moisture } \\
\text { (per cent) }\end{array}$ \\
\hline Cage & 630 & 3.71 & 3.79 & 2.02 & 74.35 \\
Loose housing** & 1,013 & 3.18 & 3.29 & 1.84 & 70.16 \\
\hline
\end{tabular}

*Results expressed as per cent of dry matter. $\quad * *$ Represents manure from pits only.

Table 3 concerns feed consumption, egg production, and fresh manure production for the two systems of management. As shown in Table 2 , the manure produced per hen was greater in the cage-housed birds. This is probably accounted for by the increased moisture content of the feces. The cage-managed hens were producing approximately 5 per cent more eggs than those hens under the loose housing method.

Table 4 contains an analysis of the composition of fresh manure obtained under two systems of management. These results indicate that the cage-managed birds cast more nitrogen, $\mathrm{P}_{2} \mathrm{O}_{5}$ and $\mathrm{K}_{2} \mathrm{O}$ as well as water in the manure as compared to the loose managed birds. When these results are corrected for moisture content, the results between the two types of management become more similar. 
The results of this study using sawdust 1 , sawdust 2 , and Zorbit as a litter are summarized in Table 5. The moisture content of the sawdust at the beginning of the experiment was highest in sawdust 2, whereas at the end of the experiment the sawdust from this pen had the lowest moisture content. The amount of manure-litter in the feces from the birds brooded on the Zorbit litter per pound of feed consumed appeared to be higher than on the sawdust litter. This may be related to moisture content, microbiological breakdown of the litter, and the microorganisms which possibly live better in the Zorbit litter, binding more of the nitrogen.

The composition of the litter removed from the brooder house for sawdust 1 , sawdust 2 , and Zorbit are compared in Table 6, and, as indicated, analysis is relatively constant between the different types of litter.

Analysis of poultry manure and litter obtained from different operations at the West Virginia University Poultry Farm is presented in Table 7. These results indicate the variation between different types of management, age of birds, and time of collecting samples. In general, the manure of the hens contained more nitrogen, $\mathrm{P}_{2} \mathrm{O}_{5}$ and $\mathrm{K}_{2} \mathrm{O}$ than that of the broilers. However, the $\mathrm{K}_{2} \mathrm{O}$ content of the manure from the different age groups is more similar than the nitrogen $\left(\mathrm{P}_{2} \mathrm{O}_{5}\right)$.

TABLE 5

MOISTURE CONTENT AND MANURE PRODUCTION DURING BROODING PERIOD

\begin{tabular}{lcccccc}
\hline \hline $\begin{array}{l}\text { Litter } \\
\text { material }\end{array}$ & \multicolumn{2}{c}{$\begin{array}{c}\text { Moisture content } \\
\text { (per cent) }\end{array}$} & $\begin{array}{c}\text { Number } \\
\text { days }\end{array}$ & $\begin{array}{c}\text { Dry } \\
\text { litter } \\
\text { per chick } \\
\text { (pounds) }\end{array}$ & $\begin{array}{c}\text { Litter } \\
\text { weight } \\
\text { per chick } \\
\text { per day }\end{array}$ & $\begin{array}{c}\text { Increase } \\
\text { per } \\
\text { pound } \\
\text { feed }\end{array}$ \\
\hline Start & End & & & & & \\
Sawdust 1 & 21.15 & 25.49 & 88 & 2.23 & 0.0252 & .269 \\
Zorbit & 28.20 & 23.63 & 90 & 2.55 & 0.0283 & .291 \\
$\quad$ Average & 11.77 & 27.77 & 80 & 2.36 & 0.0294 & .335 \\
& & & 86 & 2.37 & 0.0276 & .298 \\
\hline
\end{tabular}

TABLE 6

BROODING LITTER ANALYSIS*

\begin{tabular}{lccccc}
\hline $\begin{array}{c}\text { Litter } \\
\text { material }\end{array}$ & $\begin{array}{c}\text { Number } \\
\text { birds }\end{array}$ & $\begin{array}{c}\mathrm{N} \\
\text { (per cent) }\end{array}$ & $\begin{array}{c}\mathrm{P}_{2} \mathrm{O}_{5} \\
\text { (per cent) }\end{array}$ & $\begin{array}{c}\mathrm{K}_{2} \mathrm{O} \\
\text { (per cent) }\end{array}$ & $\begin{array}{c}\text { Average } \\
\text { moisture } \\
\text { (per cent) }\end{array}$ \\
\hline Sawdust 1 & 495 & 3.39 & 3.37 & 1.64 & 25.49 \\
Sawdust 2 & 163 & 3.19 & 3.23 & 1.71 & 23.63 \\
Zorbit & 328 & 3.34 & 3.52 & 1.68 & 27.77 \\
$\quad$ Average & & 3.31 & 3.37 & 1.68 & 25.63 \\
\hline
\end{tabular}

*Results expressed as per cent of dry matter. 


\section{COMMENTS ON MANURE MANAGEMENT}

The results presented in Table 7 indicate the composition of manure from different productions and ages of storage. The greatest loss is in nitrogen content. As nitrogen is the fertilizer element most easily lost from manure and one of the cheaper of the elements, its loss appears of minor importance when weighed against manure handling problems.

The handling of fresh manure from pits is an expensive practice because of labor required for removal, spreading conditions, and cost of pit cleaners and hauling equipment, along with high replacement costs. Wet manure is very difficult to spread and its odor is offensive.

Manure pits can hold 6-12 months' manure; the manure dries itself (burns out) with only a loss of nitrogen. The aged manure can be easily spread. Low odor and oxidation during winter can aid in keeping houses warmer. Also, it is difficult to keep pits closed in cold weather so as not to cause a temperature variation in the house with operating pit cleaners.

The management practice of allowing the manure to accumulate in the pits and placing waterers and feeders over them to increase the amount cast in the pits can be considered more desirable than pit cleaners, which are used weekly, or lagoons.

TABLE 7

COMPOSITION OF MANURE AND LITTER FROM DIFFERENT POULTRY PRODUCTIONS EXPRESSED AS PER CENT OF DRY MATTER

\begin{tabular}{|c|c|c|c|}
\hline Management system & $\begin{array}{c}\mathrm{N} \\
\text { (per cent) }\end{array}$ & $\begin{array}{c}\mathrm{P}_{2} \mathrm{O}_{5} \\
\text { (per cent) }\end{array}$ & $\begin{array}{c}\mathrm{K}_{2} \mathrm{O} \\
\text { (per cent) }\end{array}$ \\
\hline $\begin{array}{l}\text { One-day cage hen accumulation } \\
\text { One-year hen accumulation, loose }\end{array}$ & 4.52 & 3.07 & 1.66 \\
\hline housing, floor litter & 2.46 & 3.95 & 2.12 \\
\hline $\begin{array}{l}\text { One-year accumulation, loose } \\
\text { housing, under pits }\end{array}$ & 2.95 & 4.71 & 2.75 \\
\hline $\begin{array}{l}\text { One-day accumulation, loose } \\
\text { housing, under pits }\end{array}$ & 3.13 & 2.14 & 1.33 \\
\hline $\begin{array}{l}\text { Ten-week accumulation, broiler } \\
\text { brooding pen, floor litter No. } 1^{*}\end{array}$ & 2.62 & 1.76 & 1.77 \\
\hline $\begin{array}{l}\text { Ten-week accumulation, broiler } \\
\text { brooding pen, floor litter No. } 2^{*}\end{array}$ & 2.93 & 1.63 & 2.32 \\
\hline
\end{tabular}

*Indicates different broiler pens. 


\section{SUMMARY}

Poultry manure is a valuable fertilizer. Cage hens produce approximately 1.04 pounds of wet manure ( 25.65 per cent dry matter) per pound of feed consumed. The floor managed hens cast manure containing about 4 per cent less moisture than cage hens. Also, floor (loose) managed hens cast about 75 per cent of their manure into the pits (feeders and waterers were placed above the pits in this study). Fresh laying hen manure on a dry matter basis contains approximately 3.7 per cent of N, 3.8 per cent $\mathrm{P}_{2} \mathrm{O}_{5}$ and 2 per cent $\mathrm{K}_{2} \mathrm{O}$.

Broiler litter after one brood of broilers contained about 3.3 per cent $\mathrm{N}, 3.37$ per cent $\mathrm{P}_{2} \mathrm{O}_{5}$ and 1.7 per cent $\mathrm{K}_{2} \mathrm{O}$ when dry.

\section{LITERATURE CITED}

1. Yushok, W., and F. E. Bear, 1943. Poultry Manure: Its Preservation, Deodorization, and Disinfection. N. J. Agr. Exp. Sta. Bull. 707.

2. White, J.W., F. K. Holben, and A. C. Richer, 1944. Production, Composition and Value of Poultry Manure. Pa. Agr. Exp. Sta. Bull. 469.

3. Papanos, S., and B. A. Brown, 1950. Poultry Manure: Its Nature, Care and Use. Conn. (Storrs) Agr. Exp. Sta. Bull. 272.

4. Parker, M. B., H. F. Perkins, and Henry L. Fuller, 1959. Nitrogen, Phosphorus and Potassium Content of Poultry Manure and Some Factors Influencing Its Composition. Poultry Sci., Vol. 38.

5. Adams, Donald, and Ruben H. Johnson, 1961. Poultry Litter is Valuable Fertilizer. Information Sheet No. X 3572 and 73, 11-61. Agr. Ext. Ser., Univ. of Ark.

6. Hileman, Leslie H., 1959. Chemical Analysis of Broiler Litter. Ark. Farm Research, Vol. 11, No. 5. 


(5)

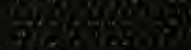

造

teis.

$\cos ^{2} \sin 2 \cos$

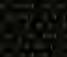

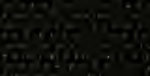

